\title{
Influence of ginger on sensory properties and shelf-life of ogi, a Nigerian traditional fermented food
}

\author{
I. A. Adesokan ${ }^{1 \star}$, O. P. Abiola ${ }^{1}$ and M. O. Ogundiya ${ }^{2}$ \\ ${ }^{1}$ Department of Science Laboratory Technology, The Polytechnic, Ibadan, Nigeria. \\ ${ }^{2}$ Department of Biology, Faculty of Science, The Polytechnic, Ibadan, Nigeria.
}

Accepted 18 March, 2010

\begin{abstract}
The influence of ginger on fermentation, acceptability and shelf life of ogi (maize pap) was investigated. Various concentrations $(1,5$ or $10 \%)$ of milled oven-dried ginger were incorporated into ogi at the beginning of fermentation. Physico-chemical and microbiological changes during fermentation and storage were determined. The $\mathrm{pH}$ of ogi samples decreased steadily and ranged between 4.08 and 5.80 and titratable acidity (TA) ranged between 0.20 and $0.77 \%$ at the end of fermentation (48 $\mathrm{h}$ ). The lactic acid bacteria (LAB) count $(\log \mathrm{cfu} / \mathrm{ml})$ ranged between 6.58 and 6.96 while the yeast count $(\log \mathrm{cfu} / \mathrm{ml})$ ranged between 5.76 and 7.84. Sensory evaluation of cooked ogi samples revealed that high concentration of ginger (10\%) adversely affected acceptability. Therefore, sample B (containing $5 \%$ ginger) was rated best in all the parameters tested. During storage, there was a slight decrease in $\mathrm{pH}$ of the samples which ranged between 3.27 and 3.65 while TA ranged between 0.009 and $0.12 \%$. Sample D (containing no ginger) had the highest coliform count of $6.83 \mathrm{log} \mathrm{cfu} / \mathrm{ml}$ while sample $\mathrm{C}$ (containing $10 \%$ ginger) had the lowest count of $6.49 \mathrm{log} \mathrm{cfu} / \mathrm{ml}$. Sample D also had the highest mould/yeast count of $9.81 \mathrm{log} \mathrm{cfu} / \mathrm{ml}$ while sample $\mathrm{C}$ had the lowest $(9.20 \mathrm{log} \mathrm{cfu} / \mathrm{ml})$.The total viable count ranged between $9.51 \mathrm{log} \mathrm{cfu} / \mathrm{ml}$ (sample C) and $10.20 \mathrm{log} \mathrm{cfu} / \mathrm{ml}$ (sample D) at the end of 8 days of storage. This study revealed that incorporation of $5 \%$ ginger into ogi significantly improved its sensory attributes, led to a relatively reduced microbial load during storage and hence an improvement in the shelf stability of the product.
\end{abstract}

Key words: Ginger, fermentation, ogi, shelf life, lactic acid bacteria, yeast count.

\section{INTRODUCTION}

Ogi is a fermented cereal porridge from West Africa which can be produced from maize (Zea mays), guinea corn (Sorghum bicolor) and millet (Pennisetum typhodenum). It serves as supplement for infant's feeding, consumed as breakfast meal by many and is also regarded as food of choice for the sick (Oyewole, 1997).

The fermentation of ogi is performed by various lactic acid bacteria including Lactobacillus $\mathrm{sp}$. and various yeasts including Saccharomyces and Candida sp. as well as Debaryomyces hansenii (Odunfa and Adeyele, 1985). The fermentation processes involved in production of ogi

\footnotetext{
*Corresponding author. E-mail: sokanisaac@yahoo.co.uk.
}

Abbreviations: TA, Titratable acidity; LAB, lactic acid bacteria; MRS, Mann, Rogosa and Sharpe Agar; PDA, potato dextrose agar. improves the sensory and nutritional qualities, availability of proteins, amino acids (lysine, threonine, methionine), carbohydrates, certain $\beta$ - group vitamins and minerals (Chavan and Kadan, 1998).

Ogi which is usually called pap, akamu and koko by people of West Africa can be processed into a slurry paste by heating in boiling water under constant stirring. It is a delicacy food product which does not receive any treatment designed to extend its shelf life. Therefore, there is a necessity to improve the shelf stability of ogi. Various foods have been preserved in order to enhance their shelf stability by using chemicals such as benzoates, nitrites and sulphites. However, some of these chemicals could have adverse effects on human health and there is a resulting trend towards less process food (Soomro et al., 2002). Originally added to change or improve taste, spices and herbs such as ginger can also enhance shelf-life because of their antimicrobial nature. 

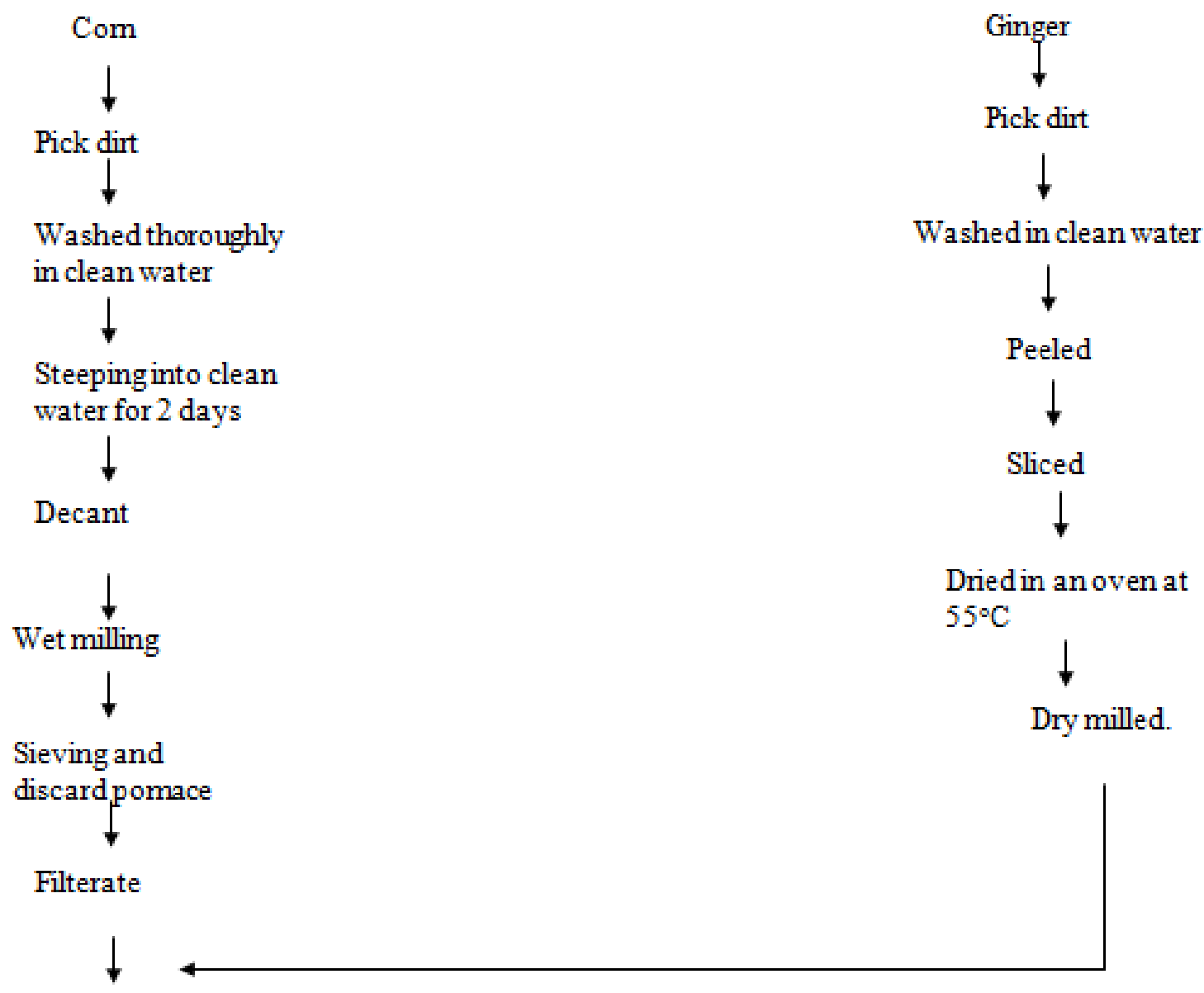

Allow to ferment and sediment for $2-3$ days

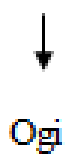

Figure 1. Flow chart for the production of ogi containing ginger (Odunfa and Adeyeye, 1985).

Some of these substances are also known to contribute to the self-defense of plants against infectious organisms (Kim et al., 2001). This study was therefore under-taken to assess the effect of ginger on the shelf life and organoleptic quality of ogi.

\section{MATERIALS AND METHODS}

\section{Collection of samples}

Maize (Z. mays) and ginger (Zingiber officinale) used in this study were purchased from Sango market in Ibadan metropolis, Nigeria. They were sorted and cleaned manually.

\section{Production of ogi}

A modified traditional preparation of ogi was employed in this study as previously described by Odunfa and Adeyele (1985). The maize obtained was washed and steeped in clean water in a plastic container with cover. The water was decanted after two days and the maize wet milled into slurry. The slurry was sieved using muslin cloth, which separates the pomace from the filterate (Figure 1).

\section{Preparation of ginger and incorporation into ogi}

The ginger was washed manually, peeled with a sharp knife and then dried in a hot air oven at $55^{\circ} \mathrm{C}$ (Ziaur-Rehman et al., 2002). The dried ginger was ground to a fine powder in a mill. Then, different concentration of the powdery ginger was added to the filtrate to prepare different batches of ogi. These batches of ogi were divided into four groups giving rise to samples $A, B, C$ and $D$. Sample A contained $99 \%$ maize and $1 \%$ ginger, sample B contained $95 \%$ maize and $5 \%$ ginger, sample C contained $90 \%$ maize and $10 \%$ ginger while sample $\mathrm{D}$ contained $100 \%$ maize and $0 \%$ ginger. After filtration, the filtrate was allowed to settle and get fermented for three days to yield ogi. The ogi produced was then 
Table 1. Effect of ginger on changes in $\mathrm{pH}$ during fermentation of ogi.

\begin{tabular}{|l|c|c|c|c|c|}
\hline Sample & $\mathbf{0 ~}$ & $\mathbf{1 2} \mathbf{h}$ & $\mathbf{2 4} \mathbf{~}$ & $\mathbf{3 6} \mathbf{~}$ & $\mathbf{4 8 ~} \mathbf{~}$ \\
\hline $\mathrm{A}$ & $5.52 \pm 0.02^{\mathrm{aa}}$ & $4.93 \pm 0.02^{\mathrm{ab}}$ & $4.48 \pm 0.02^{\mathrm{ac}}$ & $4.45 \pm 0.02^{\mathrm{ad}}$ & $4.36 \pm 0.04^{\mathrm{ae}}$ \\
$\mathrm{B}$ & $5.61 \pm 0.01^{\mathrm{ba}}$ & $4.69 \pm 0.01^{\mathrm{bb}}$ & $4.43 \pm 0.01^{\mathrm{bc}}$ & $4.36 \pm 0.02^{\mathrm{bd}}$ & $4.28 \pm 0.02^{\mathrm{be}}$ \\
$\mathrm{C}$ & $5.83 \pm 0.03^{\mathrm{ca}}$ & $4.53 \pm 0.01^{\mathrm{cb}}$ & $4.47 \pm 0.03^{\mathrm{cc}}$ & $4.29 \pm 0.01^{\mathrm{cd}}$ & $4.18 \pm 0.01^{\mathrm{ce}}$ \\
$\mathrm{D}$ & $5.74 \pm 0.02^{\mathrm{da}}$ & $4.43 \pm 0.03^{\mathrm{db}}$ & $4.17 \pm 0.01^{\mathrm{dc}}$ & $4.11 \pm 0.03^{\mathrm{dd}}$ & $4.08 \pm 0.02^{\mathrm{de}}$ \\
\hline
\end{tabular}

Values are means $(n=2) \pm$ standard deviation. Means followed by different superscripts are significantly different $(P \leq 0.05)$ along rows and columns according to Duncan multiple range test.

Table 2. Effect of ginger on changes in titratable acid (\%) during fermentation of ogi.

\begin{tabular}{|l|c|c|c|c|c|}
\hline Sample & $\mathbf{0 ~ h}$ & $\mathbf{1 2} \mathbf{~ h}$ & $\mathbf{2 4} \mathbf{h}$ & $\mathbf{3 6} \mathbf{~}$ & $\mathbf{4 8 ~} \mathbf{~}$ \\
\hline $\mathrm{A}$ & $0.29 \pm 0.01^{\mathrm{aa}}$ & $0.57 \pm 0.02^{\mathrm{ab}}$ & $0.61 \pm 0.02^{\mathrm{ac}}$ & $0.73 \pm 0.03^{\mathrm{ad}}$ & $0.73 \pm 0.02^{\mathrm{ae}}$ \\
$\mathrm{B}$ & $0.22 \pm 0.02^{\mathrm{ba}}$ & $0.49 \pm 0.02^{\mathrm{bb}}$ & $0.50 \pm 0.01^{\mathrm{bc}}$ & $0.61 \pm 0.01^{\mathrm{bd}}$ & $0.63 \pm 0.02^{\mathrm{be}}$ \\
$\mathrm{C}$ & $0.25 \pm 0.01^{\mathrm{ca}}$ & $0.60 \pm 0.01^{\mathrm{cb}}$ & $0.70 \pm 0.01^{\mathrm{cc}}$ & $0.73 \pm 0.01^{\mathrm{cd}}$ & $0.75 \pm 0.01^{\mathrm{ce}}$ \\
$\mathrm{D}$ & $0.21 \pm 0.01^{\mathrm{da}}$ & $0.45 \pm 0.01^{\mathrm{db}}$ & $0.55 \pm 0.03^{\mathrm{dc}}$ & $0.65 \pm 0.03^{\mathrm{dd}}$ & $0.76 \pm 0.01^{\mathrm{de}}$ \\
\hline
\end{tabular}

Values are means $(n=2) \pm$ standard deviation. Means followed by different superscripts are significantly different $(P \leq 0.05)$ along rows and columns according to Duncan multiple range test.

cooked under constant stirring and stored at ambient temperature for further studies.

\section{Physico-chemical analysis}

The $\mathrm{pH}$ of the various ogi samples was determined at $24 \mathrm{~h}$ interval as described by Adesokan et al. (2008) using a digital $\mathrm{pH}$ meter. The titratable acid (TA) of ogi samples was also analyzed at the same time interval by titrating $0.1 \mathrm{M} \mathrm{NaOH}$ solution and phenolphthalein as end point indicator. The titre volume of each homogenate was multiplied by 0.09 to give the percentage TA as lactic acid (Olubamiwa and Kolapo, 2008).

\section{Microbiological analysis}

One gram of each ogi sample was homogenized in $9 \mathrm{ml}$ sterile distilled water and 10 fold serial dilutions were carried out. One milliliter of the appropriate dilutions was mixed with molten medium $\left(45^{\circ} \mathrm{C}\right)$ using de Mann Rogosa and Sharpe Agar (MRS) for LAB; potato dextrose agar (PDA) supplemented with streptomycin for yeasts; MaConkey agar for coliform; and nutrient agar for total viable counts. Incubation period was $48 \mathrm{~h}$ except for yeast (72 h).

\section{Sensory evaluation}

Ogi was prepared by separately heating the slurry of the fermented ogi sample in boiling water under constant stirring using a clean stirrer to form a thick paste. Sensory evaluation of the various ogi samples was done by a 10 - man panel who are familiar with the product. The evaluated parameters were appearance, colour, aroma, taste and texture. The ratings were presented on 9 - point Hedonic scale ranging from $9=$ like extremely to $1=$ dislike extremely (Onilude et al., 2002). All data obtained were analyzed using Duncan Multiple Range Test.

\section{Determination of shelf life of cooked ogi samples}

The cooked ogi samples $(100 \mathrm{ml})$ were allowed to cool down and transferred into sterile thick transparent polythene bags, sealed and stored at ambient temperature $\left(28 \pm 2^{\circ} \mathrm{C}\right)$. The physico-chemical and microbiological changes in the stored ogi samples were also determined as described above.

\section{RESULTS}

The changes in $\mathrm{pH}$ during fermentation of ogi samples that were incorporated with ginger are presented in Table 1. There was a general reduction in $\mathrm{pH}$ of the samples and $\mathrm{pH}$ ranged between 4.08 and 4.36 post-fermentation. The TA of all the ogi samples increased significantly $(P \leq$ $0.05)$ throughout the fermentation period and it ranged between 0.63 and $0.76 \%$ (Table 2 ).

The microbiological changes in ogi samples during fermentation are presented in Figures $2 \mathrm{a}-\mathrm{c}$. There was a steady decreased in coliform population during the fermentation (Figure 2a) and ranged between 2.64logcfu/ $\mathrm{ml}$ (sample C) and 3.27 logcfu/ml (sample D) after $48 \mathrm{~h}$ of fermentation. The total viable count (Figure $2 b$ ) of all the fermented ogi samples ranged between 2.48 and 3.26 logcfu/ml after fermentation (48 h). As the fermentation progressed, the lactic acid bacteria (LAB) population (Figure $2 c)$ increased significantly $(P \leq 0.05)$. The highest LAB count was recorded for sample $D(6.69 \mathrm{cfu} / \mathrm{ml})$ while sample $C$ had the lowest LAB count of 6.56 logcfu $/ \mathrm{ml}$. The yeast count (Figure 1d) ranged between 7.48 logcfulml for sample $D$ and 5.76 cfulml for sample $C$ after $48 \mathrm{~h}$ of fermentation. 


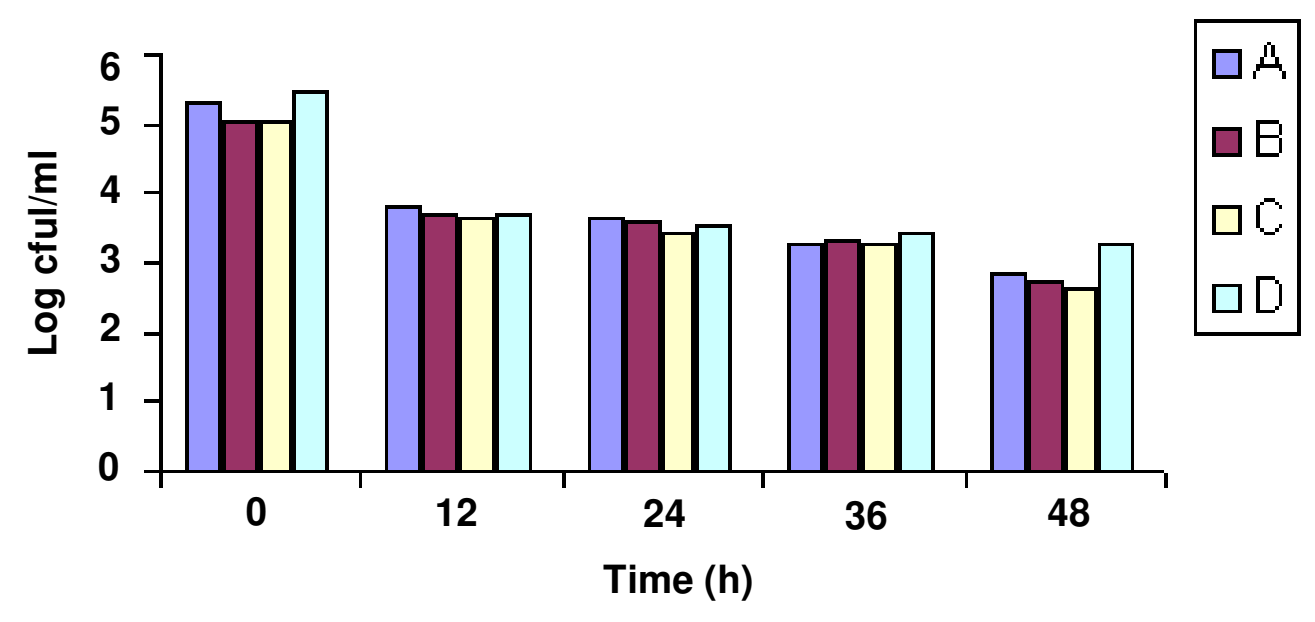

Figure 2a. Effect of ginger on coliform count during Fermentation of ogi.

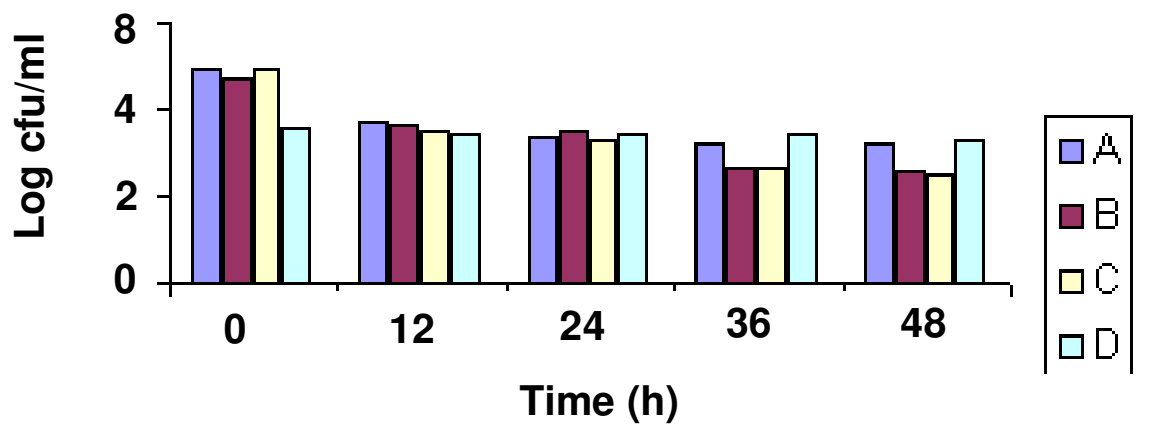

Figure 2b. Effect of ginger on total viable count during fermentation of ogi.

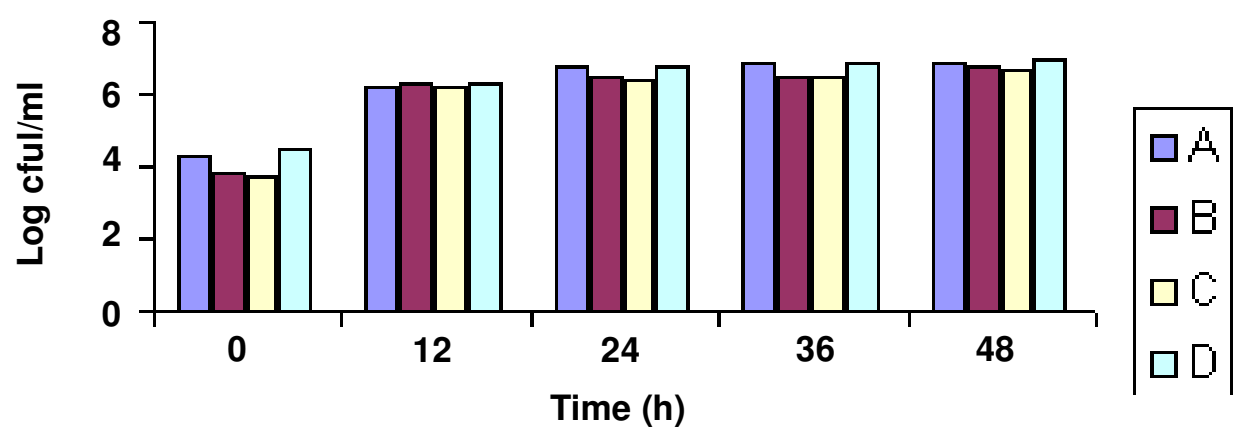

Figure 2c. Effect of ginger on lactic acid bacteria count during fermentation of ogi.

The sensory evaluation of the cooked ogi samples are presented in (Table 3 ) and sample B containing 5\% of ginger was rated best in all parameters tested which included appearance, taste, texture colour and aroma. Incorporation of $10 \%$ ginger into ogi (sample C) adversely affected its acceptability.

The changes in $\mathrm{pH}$ during the storage of cooked ogi samples are presented in Table 4. There was a slight decrease in $\mathrm{pH}$ which ranged between 3.02 and 3.21 after 8 days of storage. The TA ranged between 0.0150 and $0.083 \%$ within the same period (Table 5). The microbiological changes during the storage of cooked ogi are presented in Figures $2 \mathrm{a}-\mathrm{c}$. The coliform count was between 6.49logcfu/ml (sample C) and 6.83logcful/g (sample D) while the yeast count ranged between 9.20 logcfu/g (sample C) and 9.81 log cfu/g (sample D) at the end of storage (8 days). Moreover, the total viable count ranged between $9.51 \mathrm{log} \mathrm{cfu} / \mathrm{g}$ (sample C) and 10.4logcfu/g 
Table 3. Sensory analysis of cooked ogi samples containing different concentration of ginger.

\begin{tabular}{|l|c|c|c|c|c|}
\hline Sample & Appearance & Taste & Texture & Colour & Aroma \\
\hline A & $4.4^{\mathrm{a}}$ & $4.0^{\mathrm{a}}$ & $4.0^{\mathrm{a}}$ & $4.1^{\mathrm{a}}$ & $4.1^{\mathrm{a}}$ \\
B & $5.0^{\mathrm{b}}$ & $4.4^{\mathrm{a}}$ & $4.4^{\mathrm{a}}$ & $5.0^{\mathrm{b}}$ & $4.2^{\mathrm{a}}$ \\
C & $4.0^{\mathrm{a}}$ & $2.2^{\mathrm{c}}$ & $3.5^{\mathrm{a}}$ & $3.5^{\mathrm{a}}$ & $3.3^{\mathrm{d}}$ \\
D & $4.5^{\mathrm{b}}$ & $4.3^{\mathrm{a}}$ & $4.1^{\mathrm{a}}$ & $4.3^{\mathrm{a}}$ & $4.0^{\mathrm{a}}$ \\
\hline
\end{tabular}

Values are means $(n=2) \pm$ standard deviation. Means followed by different superscripts are significantly different $(\mathrm{P} \leq 0.05)$ along rows according to Duncan multiple range test.

Table 4. Effect of ginger on changes in $\mathrm{pH}$ during storage of cooked ogi samples.

\begin{tabular}{|l|c|c|c|c|c|}
\hline Sample & Day 0 & Day 2 & Day 4 & Day 6 & Day 8 \\
\hline A & $3.61 \pm 0.01^{\mathrm{aa}}$ & $3.46 \pm 0.02^{\mathrm{ab}}$ & $3.41 \pm 0.02^{\mathrm{ac}}$ & $3.28 \pm 0.02^{\mathrm{ad}}$ & $3.20 \pm 0.02^{\mathrm{ae}}$ \\
$\mathrm{B}$ & $3.64 \pm 0.02^{\mathrm{ba}}$ & $3.48 \pm 0.01^{\mathrm{bb}}$ & $3.43 \pm 0.02^{\mathrm{bc}}$ & $3.25 \pm 0.03^{\mathrm{bd}}$ & $3.19 \pm 0.01^{\mathrm{be}}$ \\
C & $3.65 \pm 0.01^{\mathrm{ca}}$ & $3.51 \pm 0.02^{\mathrm{cb}}$ & $3.45 \pm 0.02^{\mathrm{cc}}$ & $3.31 \pm 0.01^{\mathrm{cd}}$ & $3.21 \pm 0.01^{\mathrm{ce}}$ \\
D & $3.48 \pm 0.02^{\mathrm{da}}$ & $3.31 \pm 0.02^{\mathrm{db}}$ & $3.27 \pm 0.01^{\mathrm{dc}}$ & $3.13 \pm 0.01^{\mathrm{dd}}$ & $3.02 \pm 0.02^{\mathrm{de}}$ \\
\hline
\end{tabular}

Values are means $(n=2) \pm$ standard deviation, means followed by different superscripts are significantly different $(P \leq 0.05)$ along rows and columns according to Duncan multiple range test.

Table 5. Effect of ginger on changes in titratable acid during storage of cooked ogi samples.

\begin{tabular}{|l|c|c|c|c|c|}
\hline Sample & Day 0 & Day 2 & Day 4 & Day 6 & Day 8 \\
\hline $\mathrm{A}$ & $0.008 \pm 0.001^{\mathrm{aa}}$ & $0.016 \pm 0.002^{\mathrm{ab}}$ & $0.046 \pm 0.001^{\mathrm{ac}}$ & $0.082 \pm 0.001^{\mathrm{ad}}$ & $0.140 \pm 0.002^{\mathrm{ae}}$ \\
$\mathrm{B}$ & $0.008 \pm 0.001^{\mathrm{ba}}$ & $0.016 \pm 0.001^{\mathrm{bb}}$ & $0.037 \pm 0.001^{\mathrm{bc}}$ & $0.062 \pm 0.002^{\mathrm{bd}}$ & $0.83 \pm 0.002^{\mathrm{be}}$ \\
$\mathrm{C}$ & $0.008 \pm 0.001^{\mathrm{ca}}$ & $0.016 \pm 0.001^{\mathrm{cb}}$ & $0.035 \pm 0.002^{\mathrm{cc}}$ & $0.046 \pm 0.001^{\mathrm{cd}}$ & $0.071 \pm 0.001^{\mathrm{ce}}$ \\
$\mathrm{D}$ & $0.016 \pm 0.02^{\mathrm{da}}$ & $0.034 \pm 0.002^{\mathrm{db}}$ & $0.06 \pm 0.001^{\mathrm{dc}}$ & $0.098 \pm 0.002^{\mathrm{dd}}$ & $0.150 \pm 0.001^{\mathrm{de}^{\mathrm{de}}}$ \\
\hline
\end{tabular}

Values are means $(n=2) \pm$ standard deviation means followed by different superscripts are significantly different $(P \leq 0.05)$ along rows and columns according to Duncan multiple range test.

(sample D) within the same period.

Furthermore, the ogi samples that did not contain ginger (sample D) and the one containing $1 \%$ of ginger (sample A) showed signs of spoilage after 3 days while samples that contained $5 \%$ ginger (sample B) and $10 \%$ ginger (sample $\mathrm{C}$ ) were in good condition till the end of the 8 days of storage.

\section{DISCUSSION}

There was a steady decrease in the $\mathrm{pH}$ during the fermentation while there was a significant increase in the TA in all the ogi samples. This might be as a result of production of lactic acid by fermentative organisms responsible for the fermentation of ogi. This observation is in agreement with the report of previous studies (Odunfa and Adeyele, 1985).

The population of coliform organisms and total viable count during the fermentation of ogi samples containing different concentration of ginger was relatively low. This might be due to the presence of antibacterial compounds such as gingerol, shogaols, vitamin $A$ and $B$, paradol and zingerine in ginger (Kolapo et al., 2007).

The population of yeast and $L A B$ increased during fermentation. Various studies have implicated yeast and
LAB in the fermentation of ogi where they contribute to the flavour and aroma development of ogi (Odunfa and Adeyele, 1985; Oyewole, 1997).

Though high concentration of ginger (10\%) adversely affected acceptability, the sample containing $5 \%$ ginger improved the sensory property of ogi and was rated best in all parameters tested. From time immemorial, several spices have been employed for their aromatic, medicinal and flavoring characteristics. During the 8 days storage of ogi samples, a significant decrease in $\mathrm{pH}$ was observed with corresponding increase in TA. This could be as a result of fermentation of the product during storage. Ogi samples produced with different concentration of ginger had lower microbial count than the sample produced without ginger. This might be as a result of antimicrobial activities of ginger incorporated into the samples. This result agreed with the finding of Kolapo et al. (2007) who reported a reduction in bacterial population in soybean

daddawa preserved with dichloromethane extract of ginger.

Incorporation of ginger into ogi relatively reduced oxidative rancidity during storage of cooked ogi samples. Ginger is known to contain several antioxidants compounds 
such as gingerol, gingerdiol and shogaol. Most of these compounds possess antimicrobial activity against food spoilage organisms.

This study revealed that incorporation of $5 \%$ ginger into ogi led to a relatively improved sensory attributes, a reduction in microbial load during storage and hence an improved shelf life.

\section{REFERENCES}

Adesokan IA, Avanrenren ER, Salami RT, Akinlosotu IO, Olayiwola DT (2008). Management of spoilage and pathogenic organisms during fermentation of nono-an indigenous fermented milk product in Nigeria. J. Appl. Biosci. 11: 564-569.

Kim D, Lim D, Bai S, Chum S (2001). Fermentation characteristic of whole soybean meju model system inoculated with four Bacillus strains. J. Food Sci. Technol. 29: 1006-1015.
Olubamiwa AO, Kolapo AL (2008). Evaluation of nutritional composition and acceptability of soy-coconut milk-based yoghurt fermented with different starter cultures Food 1: 65-69.

Onilude AA, Sanni AI Olaoye OA, Ogunbawo ST (2002). Influence of lactic cultures on the quality attributes of tsire, a West African stick meat. World J. Microbiol. Biotechnol. 18: 615-619.

Oyewole OB (1997) Lactic acid fermented foods in Africa and health benefits. Food Control, 8: 5-6.

Soomro AH, Masud T, Awaar K (2002). Role of lactic acid bacteria (LAB) in food preservation and human health-A Review. Pak. J. Nutr. 1: $20-24$.

Zia-ur-Rehman A, Salariya AM, Farzana H (2003). Antioxidant activity of ginger in sunflower oil. J. Sci. Food Agric. 83: 624-629.
Kolapo AL Popoola TOS, Sanni MO, Afolabi RO (2007). Preservation of soybean daddawa condiment with dichloromethane extract of ginger. Res. J. Microbiol. 3: 254-259.

Odunfa SA, Adeyele S (1985). Microbiological changes during the traditional fermentation of ogi-baba,a West African fermented sorghum gruel. J. Cereal Sci. 3: 173-180. 